\title{
Interstitial microduplication at 2p11.2 in a patient with syndromic intellectual disability: 30-year follow-up
}

Kyung Ran Jun ${ }^{1}$, Reinhard Ullmann², Saadullah Khan ${ }^{3}$, Lawrence C Layman ${ }^{4,5}$ and Hyung-Goo Kim ${ }^{4^{*}}$

\begin{abstract}
Background: Copy number variations at 2p11.2 have been rare and to our knowledge, no abnormal phenotype with an interstitial 2p11.2 duplication has yet been reported. Here we report the first case with syndromic intellectual disability associated with microduplication at 2p11.2.

Results: We revisited a white female subject with a chromosome translocation, $t(8 ; 10)(p 23 ; q 23)$ mat and a 10q telomeric deletion suspected by G-banding 30 years ago. This female with severe intellectual disability, no speech, facial dysmorphism, intractable epilepsy, recurrent infection, and skeletal abnormalities has been observed from the birth until her death. The karyotype analysis reconfirmed the previously reported chromosome translocation with a revision as $46, X X, t(8 ; 10)(p 23.3 ; q 23.2)$ mat by adding more detail in chromosomal sub-bands. The array comparative genomic hybridization, however, did not detect the $10 \mathrm{q}$ terminal deletion originally reported, but instead, revealed a 390 kb duplication at 2p11.2; 46,XX,t(8;10)(p23.3;q23.2)mat.arr[hg 19] 2p11.2(85469151×2,85474356$85864257 \times 3,85868355 \times 2$ ). This duplication region was confirmed by real-time quantitative PCR and real-time reverse transcriptase quantitative PCR.
\end{abstract}

Conclusions: We suggest three positional candidate genes for intellectual disability and recurrent infection based upon gene function and data from real-time reverse transcriptase quantitative PCR - VAMP8 and RNF181 for intellectual disability and CAPG for recurrent infection.

Keywords: Array CGH, CAPG, Copy number variation, Duplication, Intellectual disability, Recurrent infection, RNF181, 2p11.2, VAMP8

\section{Background}

A variety of terminal $2 \mathrm{p}$ duplications known as partial $2 p$ trisomy are the unbalanced chromosomal rearrangements resulting from malsegregation of various balanced translocations [1-3]. Interpretation of the clinical phenotypes of carriers with these unbalanced translocations is complicated due to the co-existence of terminal monosomy and terminal trisomy. Different isolated duplications within the $2 \mathrm{p}$ region had been reported in more than 20 patients, but they vary in size and location, ranging from 2 p12 to 2 p25 [4-7]. These duplications are

\footnotetext{
* Correspondence: hkim@gru.edu

${ }^{4}$ Section of Reproductive Endocrinology, Infertility \& Genetics, Department of Obstetrics and Gynecology, Institute of Molecular Medicine and Genetics, Medical College of Georgia, Georgia Regents University, 1120 15th Street, Augusta, Georgia

Full list of author information is available at the end of the article
}

associated with a syndromic phenotype including intellectual disability, growth and psychomotor retardation, delayed bone age, congenital heart abnormalities, pulmonary hypoplasia, hypoplastic kidney, genital anomaly, anencephaly, neural tube defects, finger and toe abnormalities, or dysmorphic facial features encompassing hypertelorism, prominent forehead, broad nasal bridge, low-set ear, and micrognathia [4-7]. Because the size and location of these $2 p$ duplications may vary from individual to individual, comparison of overlapping regions for defining a minimal candidate region associated with a particular phenotype will be a useful strategy for identifying the causative gene as exemplified in the mapping of deletions $[8,9]$.

Due to the limited resolution of banding and staining patterns of chromosomes in the pre-FISH (FISH-fluorescent in situ hybridization) and pre-CGH (CGH-comparative 
genomic hybridization) era, it is not uncommon to find misinterpretations of cytogenetic aberrations in the reported cases, which complicated attempts to assign a unique phenotype to a specific chromosome band. Here we revisited a case reported 30 years ago [10] and failed to confirm an ostensible 10q deletion. Instead, we identified a cryptic 2 p11.2 microduplication by a microarray in the affected female subject. Some of her clinical features were developed years later in her life. To our knowledge, this is the first case with syndromic intellectual disability associated with an interstitial 2p11.2 duplication. Genotype/ phenotype relationships have been discussed.

\section{Results}

\section{Clinical report in a $\mathbf{3 0}$ year time period}

The patient is a 30 year old white female with severe intellectual disability, a severe static encephalopathy, medically intractable epilepsy, and facial dysmorphism. She was first evaluated at the age of 10 months because of gastroenteritis and middle ear infection [10]. At that time, her height, weight and head circumference were in the 3rd percentile for chronological age. She is the first living child of healthy non-consanguineous marriage. The father was 42 years old and the mother with a previous spontaneous abortion was 26 years old at the birth of their daughter. Prenatal screening demonstrated normal alpha-fetoprotein levels for gestational age and a normal ultrasound, but studies indicated an Rh-sensitized status. The subject was a 2,700 g female at 35 weeks of gestation born by cesarean section.

After at the age of one year, she was able to sit and look into the eyes of anyone who spoke to her with responding smiles. However, the direction of her gaze was difficult to determine because of her convergent strabismus. She did not show any autistic behavior as evidenced by her continual demands on her mother. At the age of two years, she started to babble words such as mama, water, etc. Her facial appearances from 3 years to 30 years of age are shown chronologically in Figures 1A-D. When she was evaluated at 10 months of age, her phenotype was as follows: hypotonia, long and narrow palpebral fissures, long eyelashes, prominent eyebrow, mild hypertelorism, broad nasal bridge, long philtrum, short neck, the trunk and extremities of normal proportion with hirsutism, redundant subcutaneous tissue on arms, legs, and the dorsum of hands and feet, bilateral simian crease, infantile external genitalia, and convergent strabismus [10]. She began walking at 5 years of age.

At 9 years, she was diagnosed with epilepsy, reporting myoclonic seizures with atypical absences. The electroencephalography (EEG) showed generalized $2 \mathrm{~Hz}$ spikeand-slow waves. At this time she lost her ability to verbalize simple words. She was started on valproic acid and then vigavatrin was added. Her EEG then showed anterior right temporal epileptiform discharges. Because of valproic acid side effects including hypothyroidism, teeth, and gum damage, this medication was replaced by clonazepam. Despite treatment, she continued to have seizures. She frequently had complex partial seizures with a moderate response to lamotrigine and oxcarbazepine. Olanzapine was also administered because of psychomotor excitation with episodes of autoaggression. Brain MRI without contrast revealed cortical dysplasia and asymmetric lateral ventricles with an enlarged right ventricle at the age of 14 years (Figure 2). Corrective surgery for her strabismus was performed at 12 years of age. In addition, orthopedic surgery for her severe flaccid flatfeet was also successfully performed by lengthening of the calcaneus with a homologous graft from her iliac crest at 16 years of age (Figures $1 \mathrm{E}-\mathrm{H}$ ).

In her latest evaluation, the 30-year-old subject still suffers from intractable epilepsy. She has had growth, but she is below the third percentile. She has a severe mental and psychomotor delay with independent gait, but still no language. Additionally, she has global muscular atrophy, hypotonia, joint hyperflexibility (except for her elbows and knees which were rigid), scoliosis, and facial dysmorphism characterized by a long thin face with prognathia and high nasal bridge (Figure 1D). The mouth is usually open with sialorrhea, a full lower lip and a thin upper lip, showing thickened gums (Figure 1C), possibly related to antiepileptic medications. Several teeth are missing due to the first exodontia surgery at age 22 and the subsequent exodontia surgery of her remaining teeth, which showed decay at the age of 30 . Her maxillofacial malformation worsened during adolescence with repeated changes of antiepileptic medications, which also caused inflammatory gum processes, hypersalivation, tooth loss, dental caries, and retraction of bone.

The proband also has a low hairline, backward rotation of the ears, and small hands with hypoplastic fingernails and dry palmar and plantar surfaces. In addition, she has a fungal infection on the skin of her hands exclusively that has provoked a severe dermatitis (Figures 1I and J). This infection has been recurrent throughout her life. A recent brain MRI performed at the age of 29 did not confirm the previous diagnosis of cortical dysplasia, suggesting natural healing of the affected brain area. She died at the age of 31 years and 8 months under a grandmal type of convulsion which took place during her bath and could not be controlled.

\section{The detection of microduplication at $2 \mathrm{p} 11.2$}

Prenatal cytogenetic analysis using amniotic fluid showed a female fetus with an inherited chromosome translocation, $\mathrm{t}(8 ; 10)(\mathrm{p} 23 ; \mathrm{q} 23)$ shared with her mother. The father's karyotype was normal. When she was evaluated for developmental delay, her karyotype was reported as monosomy 

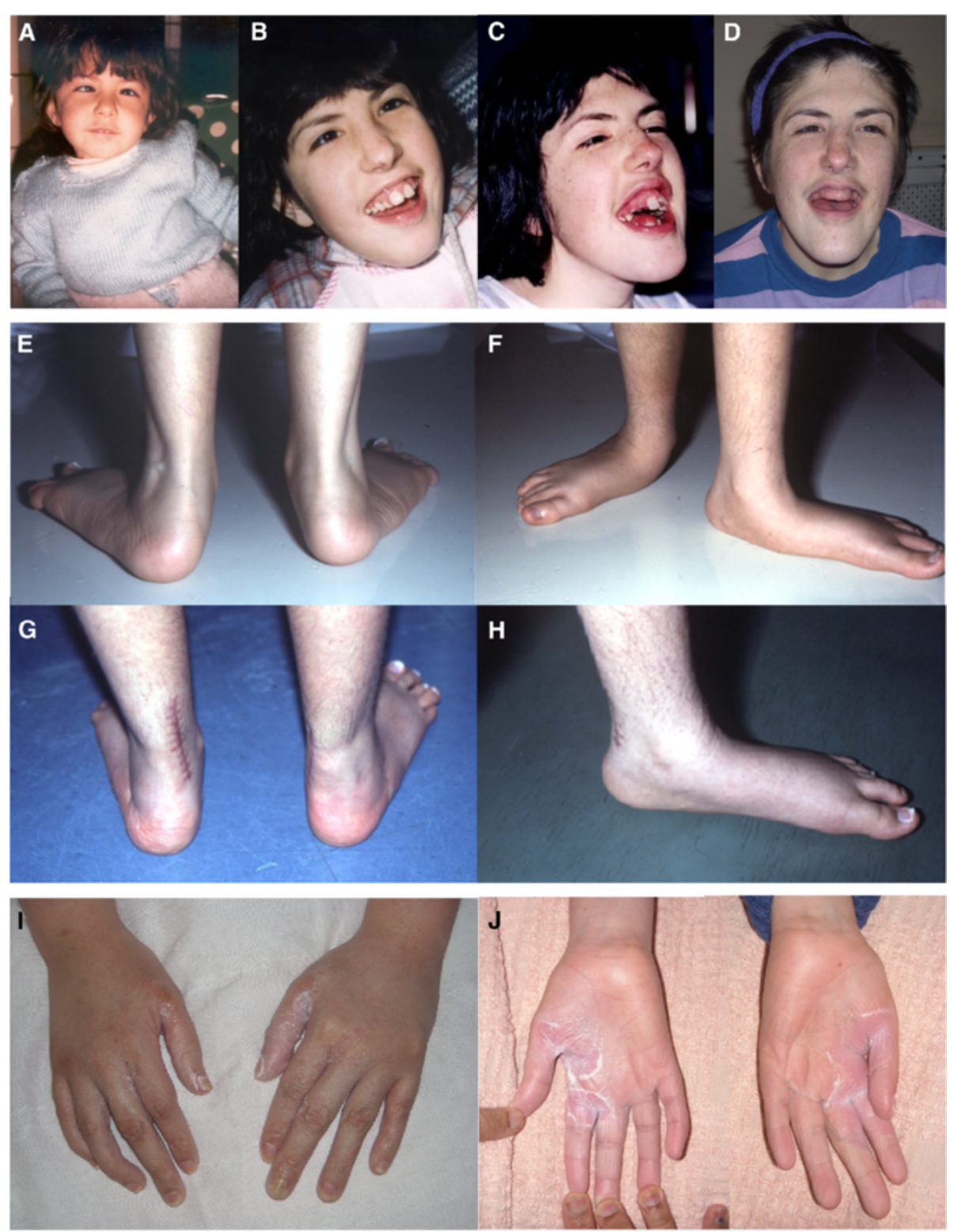

Figure 1 Facial phenotype of the patient. The frontal view of patient was shown chronologically at the age of 3 years showing strabismus (A), at the age of 12 years after the surgery to correct strabismus. She had normal teething before taking anticonvulsant (B), at the age of 18 years showing the side effects of damaged teeth and thickened gum from antiepileptic drugs (C), and at the age of 30 years after the exodontias surgery of the rest of decayed teeth with facial dysmorphism characterized by long and thin face with prognathia and high nasal bridge (D). She also had severe flaccid flatfeet $(\mathbf{E}, \mathbf{F})$, which were successfully corrected by an orthopedic surgery lengthening the calcaneus with a homologuous graft from the iliac crest at the age of 16 years $(\mathbf{G}, \mathbf{H})$. At the age of 31 years, she had fungal infection on the skin of her both hands that provoked a severe dermatitis $(\mathbf{I}, \mathbf{J})$.

10q, with a deletion from 10q23 to 10qter [10]. However, FISH using probes in this region did not confirm this deletion (data not shown). Another high resolution karyotype performed on peripheral blood lymphocytes using standard methods and G-banding techniques confirmed that the patient has a chromosome translocation, 46,XX,t( $8 ; 10)(\mathrm{p} 23.3 ; \mathrm{q} 23.2)$ mat, shared with her asymptomatic mother and younger sister. Methylation studies of the 15q11-q13 region demonstrated the presence of two fragments with sizes of $6.6 \mathrm{~kb}$ and $3.4 \mathrm{~kb}$, indicating normal methylation status. Therefore a deletion or uniparental disomy in the critical imprinted region of Prader-Will and Angelman syndromes was highly unlikely (data not shown) However, array CGH analysis revealed a heterozygous $390 \mathrm{~kb}$ interstitial duplication (Chr2: 85,474,356-85,864,257 [hg 19]) in band 2p11.2 with a maximum size of $399 \mathrm{~kb}$ (Chr2: 85,469,15185,868,355 [hg 19]) (Figure 3A). 


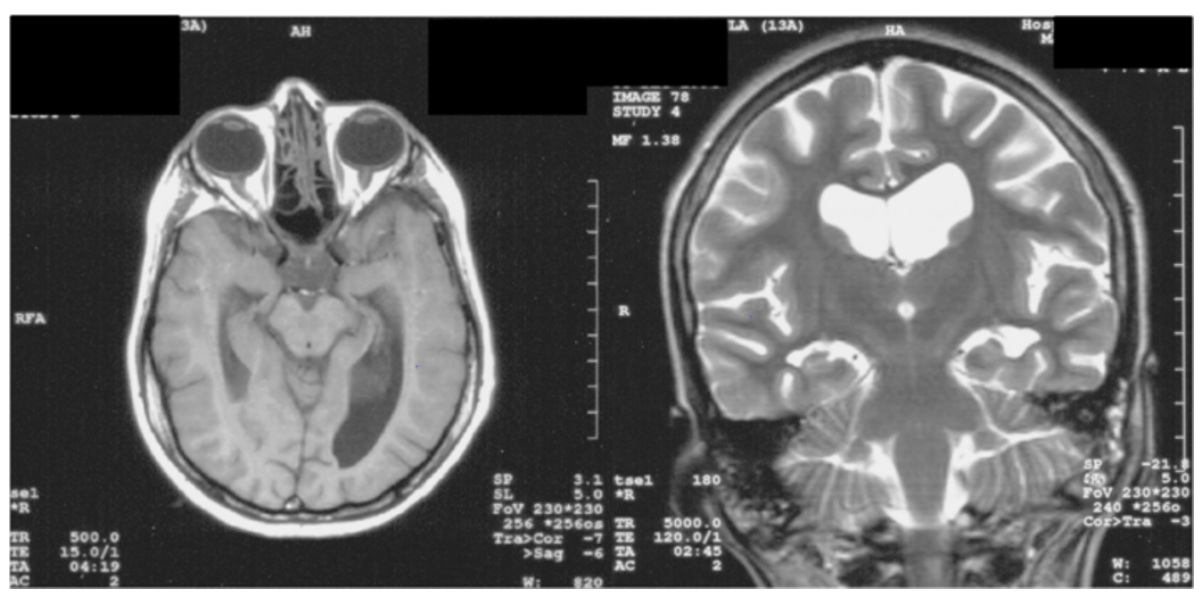

Figure 2 The brain MRI views without contrast at the age of $\mathbf{1 4}$ years. They showed cortical dysplasia and asymmetric lateral ventricles with an enlarged right ventricle.

Based on the aberrant karyotype and array CGH result found in the patient, the nomenclature is revised as 46, $\mathrm{XX}, \mathrm{t}(8 ; 10)(\mathrm{p} 23.3 ; \mathrm{q} 23.2)$ mat.arr[hg 19] 2p11.2(85469151x2, 85474356-85864257x3,85868355x2).

\section{The confirmation of duplicated region by real-time quantitative PCR}

The duplicated region was detected in the patient only and confirmed by real-time quantitative PCR (qPCR) (Figure 3C). The mRNA expression levels of TCF7L1 and USP39 were not different among patient (II-1), her mother (I-2), or her sister (II-2) by qRT-PCR using two primer pairs from each gene (Table 1 , data not shown). The mRNA expression levels of CAPG, VAMP8, and RNF181 were doubled in the duplication patient compared to her two normal sister and mother by qRT-PCR using two primer pairs designed within CAPG and one primer pair from $V A M P 8$ and $R N F 181$, respectively (Figures 3D-F, Table 1). No amplicon of the putative fusion gene USP39/TCF7L1 was obtained from RT-PCR, suggesting it is not expressed (Figure 4, Table 1).

\section{Discussion}

It may seem surprising that the reinvestigation of this chromosome translocation, 46,XX,t $(8 ; 10)(\mathrm{p} 23.2 ; \mathrm{q} 23.2)$ mat has spanned a 30 year time period. Since this chromosome translocation was inherited from the healthy mother to the affected and unaffected daughters (Figure 3B), a pathological role of this translocation in the phenotype of the affected daughter was excluded. A previously reported 10q23-qter deletion was ruled out by FISH and array $\mathrm{CGH}$, the latter of which instead identified a cryptic $390 \mathrm{~kb}$ duplication at 2p11.2 encompassing 15 genes (Figure 3A, Table 2). This genomic duplication was confirmed by qPCR (Figure 3C), suggesting its pathogenic role as a cryptic chromosome rearrangement not readily detected by conventional karyotype analysis done in 1983 [10]. The de novo status of this duplication is likely, but could not be confirmed because her father is unwilling to participate.

Among the genes duplicated, the following $\mathrm{CNVs}$ have been identified in healthy control persons, thereby potentially ruling out them as candidate genes if gene dosage effect is underlying mechanism: a $7.8 \mathrm{~kb}$ deletion involving all 4 exons within the gene TGOLN2 [11], a $28 \mathrm{~kb}$ duplication containing two genes, MAT2A and GGCX [12], a $36 \mathrm{~kb}$ deletion encompassing whole gene RNF181 [13], and a $12 \mathrm{~kb}$ deletion encompassing exons 4-6 [14] and a $5.6 \mathrm{~kb}$ deletion encompassing exons 7-9 [15] of the gene USP39 (Table 2).

Interstitial deletions encompassing 2p11.2 are particularly rare, with only seven cases reported to date $[16,17]$. Among them, the interstitial deletion of $2 \mathrm{p} 11.2-2 \mathrm{p} 12$ was confirmed in only three cases by array CGH [16], high-resolution $\mathrm{CGH}$ [17], or qPCR [17]. These deletions ranged in size from 7.5 to $11.4 \mathrm{Mb}$, encompassing the $390 \mathrm{~kb}$ duplicated region of our case. The patient with an 11.4 Mb deletion had psychomotor retardation, mild cutaneous syndactylies, pectus carinatum, hyperlordosis, clubfeet, single umbilical artery, and facial abnormalities, such as low-set ears, broad nasal bridge, frontal bossing, and dolichocephaly [16]. In family 3, a son with a 7.5 Mb deletion presented with impairment of physical development, and intellectual disability, language delay including a pronunciation problem, suspected epilepsy, recurrent Wilms tumor, a large head with frontal bossing, a flat face, and low-set abnormally molded ears [17]. His mother with the same deletion had features similar to her son, such as abnormally molded ears, a severe pronunciation problem, and intellectual disability [17].

Two obstacles hampered us to compare the overlapping phenotype and genomic regions between our duplication patient and three patients with deletions encompassing 


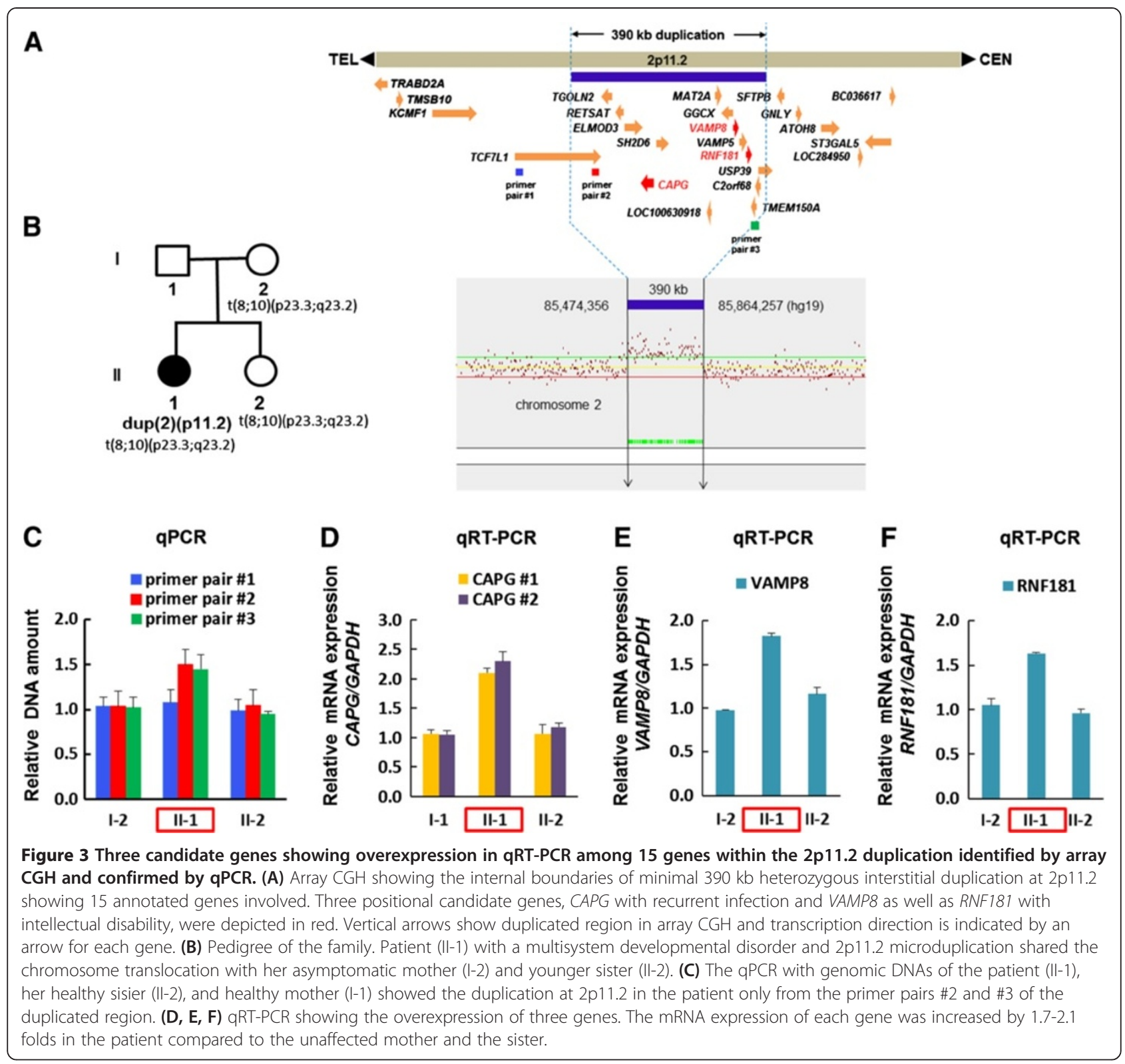

2p11.2. Firstly, we do not know whether a dosage effect of genes is involved in both deletions and our duplication, and whether increased or decreased gene dosage would give rise to the same phenotype. Secondly, the genomic regions of 7 reported deletion cases are so large that they could contain more than one gene for a specific phenotype such as intellectual disability. In this circumstance, the simple comparison of overlapping regions in two groups of inappropriately different sized CNVs is not meaningful because our duplication is only $390 \mathrm{~kb}$ and the smallest deletion among 7 deletion cases is $7.5 \mathrm{Mb}$ containing a large number of genes.

Therefore, we analyzed known and deduced functions of genes within the duplicated region. While the chromosome band 2p11.2 of 7.2 Mb contains many genes, fifteen annotated genes are located in $390 \mathrm{~kb}$ duplicated region of our case; TCF7L1, TGOLN2, RETSAT, ELMOD3, CAPG, SH2D6, LOC100630918, MAT2A, GGCX, VAMP8, VAMP5, RNF181, TMEM150A, C2orf68, and USP39 (Figure 3A, Table 2). These are all protein-coding genes, except the non-coding RNA LOC100630918.

The multisystemic disorder in our patient suggests that it is caused by more than one gene or by a single gene encoding a transcription factor regulating various target genes. Among the genes in the duplicated region, TCF7L1 (transcription factor 7-like 1, formerly named TCF3, MIM 604652) is a mediator of the WNT signaling pathway [18]. This gene encodes a transcription factor, which is a member of the T-cell factor/lymphoid enhancer factor. Importantly, TCF7L1 physically interacts with 
Table 1 Primers used for qPCR, qRT-PCR, and RT-PCR

\begin{tabular}{|c|c|c|c|c|}
\hline Primer name & Gene name (GenBank accession number) & exon number & Primer sequence $\left(5^{\prime} \rightarrow 3^{\prime}\right)$ & ${ }^{*} \mathrm{Tm}\left({ }^{\circ} \mathrm{C}\right)$ \\
\hline \multicolumn{5}{|l|}{ qPCR } \\
\hline primer pair \#1F & TCF7L1 & exon1 & F: ACGAGCTGATCCCCTTCC & 60.16 \\
\hline primer pair \#1R & (NM_031283) & & R: CTGCTCTGGTTCTCCGACTC & 60.14 \\
\hline primer pair \#2F & TCF7L1 & exon12 & F: GCAAGAAGCCATGTGTTCAG & 59.45 \\
\hline primer pair $\# 2 R$ & (NM_031283) & & R: GGTTTCTGGTTTGGTGGTGA & 60.79 \\
\hline primer pair \#3F & TMEM150A & exon8 & F: TACGAGTTTGGGGCAGTCTC & 60.25 \\
\hline primer pair \#3R & (NM_001031738) & & R: CCTCCCCAGACCTTAGATCA & 59.79 \\
\hline GAPDH-F & GAPDH & exon6 & F: GATCATCAGCAATGCCTCCT & 60.4 \\
\hline GAPDH-R & (NM_001289745) & & R: ATGGCATGGACTGTGGTCAT & 60.4 \\
\hline \multicolumn{5}{|l|}{ qRT-RCR } \\
\hline primer pair \#1F & TCF7L1 & exon1 & F: ACGAGCTGATCCCCTTCC & 60.16 \\
\hline primer pair \#1R & (NM_031283) & & R: CTGCTCTGGTTCTCCGACTC & 60.14 \\
\hline primer pair \#2F & TCF7L1 & exon12 & F: GCAAGAAGCCATGTGTTCAG & 59.45 \\
\hline primer pair $\# 2 R$ & (NM_031283) & & R: GGTTTCTGGTTTGGTGGTGA & 60.79 \\
\hline primer pair \#4F & USP39 & exon5 & F: ATGTTCCTCCTCTCCGGAAC & 60.46 \\
\hline primer pair \#4R & (NM_006590) & & R: AGCATCTCATGGGGAGACAC & 60.08 \\
\hline primer pair \#5F & USP39 & exon10 & F: GACCTCATTGCCAACATCGT & 60.23 \\
\hline primer pair \#5R & (NM_006590) & exon11 & R: GTGTGATCATCTGGGGAAGG & 60.33 \\
\hline CAPG-1F & CAPG & exon3 & F: CTCCATTCCCAGGCTCAGT & 60.21 \\
\hline CAPG-1R & (NM_001747) & & R: GAAACCTCTTCTGGGCCATT & 60.44 \\
\hline CAPG-2F & $C A P G$ & exon9 & F: CGAAAAGCGAATGAGAAGGA & 60.46 \\
\hline CAPG-2R & (NM_001747) & exon10 & R: CCACCCTCATTTCCAGTCC & 60.31 \\
\hline VAMP8-F & VAMP8 & exon 3 & F: GAGGAAGCCAGTGAAGGTGG & 60.6 \\
\hline VAMP8-R & (NM_003761) & & R: CAGATCCTCTGTCTTGTTGCG & 59.44 \\
\hline RNF181-F & RNF181 & exon1 & F: ACCAACATGCTGCTGGAGC & 60 \\
\hline RNF181-R & (NM_016494) & & R: TCTCAACCACAGTCTTGGCAG & 59 \\
\hline GAPDH-F & GAPDH & exon6 & F: GATCATCAGCAATGCCTCCT & 60.4 \\
\hline GAPDH-R & (NM_001289745) & & R: ATGGCATGGACTGTGGTCAT & 60.4 \\
\hline \multicolumn{5}{|l|}{ RT-PCR } \\
\hline Fusion-USP39-F & USP39 & exon6 & F: ATGTTCCTCCTCTCCGGAAC & 60.46 \\
\hline Fusion-TCF7L1-R & TCF7L1 (USP39/TCF7L1) & exon5 & R: TGTCTTTGGATCGATCTCTGG & 60.20 \\
\hline
\end{tabular}

*Tm: melting temperature.

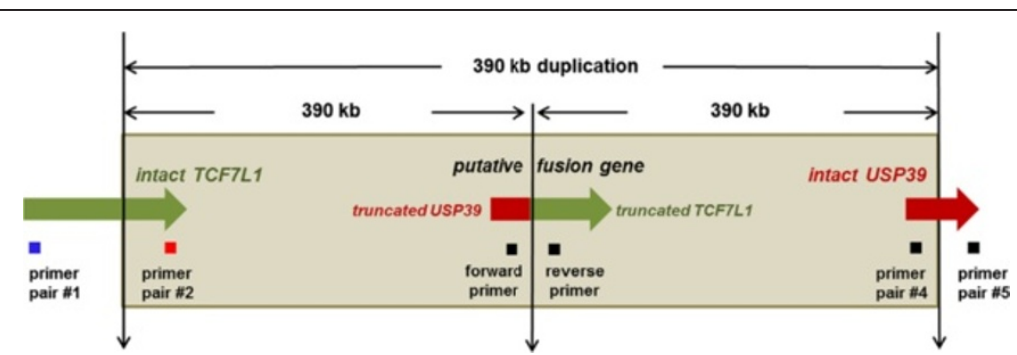

Figure 4 Prediction of a putative fusion gene USP39/TCF7L1 due to the duplication. If the distal and proximal duplication breakpoints truncate two genes, TCF7L1 and USP39, it will produce a putative fusion gene USP39/TCF7L1, because the transcription direction of both genes is same. In order to amplify the putative fusion gene, a forward primer Fusion-USP39-F and a reverse primer Fusion-TCF7L1-R were used (Table 1). 
Table 2 Genes located at the duplicated region of 2 p11.2

\begin{tabular}{|c|c|c|c|c|c|}
\hline Gene symbol & Gene name & Encoded protein & Function & Related disease & Remark \\
\hline TCF7L1 & $\begin{array}{l}\text { Transcription factor } \\
\text { 7-like } 1 \text { (T-cell } \\
\text { specific, HMG-box) }\end{array}$ & $\begin{array}{l}\text { Transcription factor } \\
\text { 7-like } 1 \text { (a member of } \\
\text { T cell factor/lymphoid } \\
\text { enhancer factor family } \\
\text { of transcription factors) }\end{array}$ & $\begin{array}{l}\text { Mediation of Wnt } \\
\text { signaling pathway, } \\
\text { regulation of cell } \\
\text { cycle genes and } \\
\text { cellular senescence }\end{array}$ & None & $\begin{array}{l}\text { Homozygous mutant mice } \\
\text { exhibit severe embryological } \\
\text { defects particularly affecting the } \\
\text { cardiovascular system, nervous } \\
\text { system, and digestive system. } \\
\text { Not affected by our duplication } \\
\text { based on qRT-PCR result. }\end{array}$ \\
\hline TGOLN2 & $\begin{array}{l}\text { Trans-golgi network } \\
\text { protein } 2\end{array}$ & $\begin{array}{l}\text { Trans-Golgi network } \\
\text { integral membrane } \\
\text { protein } 2 \text { precursor }\end{array}$ & $\begin{array}{l}\text { Exocytic vesicle } \\
\text { formation }\end{array}$ & None & $\begin{array}{l}\text { No knock-out mice. A } 7.8 \mathrm{~kb} \\
\text { deletion involving all } 4 \text { exons } \\
\text { within the gene was reported in } \\
\text { a normal control person. }\end{array}$ \\
\hline RETSAT & Retinol saturase & $\begin{array}{l}\text { All-trans-retinol 13, } \\
\text { 14-reductase } \\
\text { precursor }\end{array}$ & $\begin{array}{l}\text { All-trans-retinol } \\
\text { 13,14-reductase } \\
\text { activity, } \\
\text { oxidoreductase } \\
\text { activity }\end{array}$ & None & No knock-out mice. \\
\hline ELMOD3 & $\begin{array}{l}\text { ELMO/CED-12 } \\
\text { domain containing } \\
3\end{array}$ & $\begin{array}{l}\text { ELMO domain- } \\
\text { containing protein } 3 \text {, } \\
\text { isoform } a, b\end{array}$ & $\begin{array}{l}\text { Phagocytosis and } \\
\text { cell migration }\end{array}$ & $\begin{array}{l}\text { Deafness, autosomal } \\
\text { recessive } 88 \text { (OMIM 615429) }\end{array}$ & No knock-out mice. \\
\hline CAPG & $\begin{array}{l}\text { Capping protein } \\
\text { (actin filament), } \\
\text { gelsolin-like }\end{array}$ & $\begin{array}{l}\text { Macrophage-capping } \\
\text { protein }\end{array}$ & $\begin{array}{l}\text { Control of actin- } \\
\text { based motility in } \\
\text { non-muscle cells }\end{array}$ & None & $\begin{array}{l}\text { Inactivation of this loci results in } \\
\text { impaired immune cell motility } \\
\text { which manifests in homozygous } \\
\text { mutant mice as increased } \\
\text { susceptibility to some bacterial } \\
\text { infections. }\end{array}$ \\
\hline SH2D6 & $\begin{array}{l}\text { SH2 domain } \\
\text { containing } 6\end{array}$ & $\begin{array}{l}\text { SH2 domain- } \\
\text { containing protein } 6\end{array}$ & Unknown & None & No knock-out mice. \\
\hline LOC100630918 & $\begin{array}{l}\text { Uncharacterized } \\
\text { non-coding RNA }\end{array}$ & non-coding RNA & Unknown & None & No knock-out mice. \\
\hline MAT2A & $\begin{array}{l}\text { Methionine } \\
\text { adenosyltransferase } \\
\text { II, alpha }\end{array}$ & $\begin{array}{l}\text { S-adenosylmethionine } \\
\text { synthase }\end{array}$ & $\begin{array}{l}\text { Production of S- } \\
\text { adenosylmethionine } \\
\text { from methionine } \\
\text { and ATP }\end{array}$ & None & $\begin{array}{l}\text { No knock-out mice. A } 28 \mathrm{~kb} \\
\text { duplication containing this gene } \\
\text { and GGCX was reported in a } \\
\text { normal control person. }\end{array}$ \\
\hline GGCX & $\begin{array}{l}\text { Gamma-glutamyl } \\
\text { carboxylase }\end{array}$ & $\begin{array}{l}\text { Vitamin K-dependent } \\
\text { gamma-carboxylase }\end{array}$ & $\begin{array}{l}\text { Posttranslational } \\
\text { modification of } \\
\text { vitamin K- } \\
\text { dependent protein }\end{array}$ & $\begin{array}{l}\text { Autosomal recessive } \\
\text { pseudoxanthoma elasticum- } \\
\text { like disorder with multiple } \\
\text { coagulation factor deficiency } \\
\text { (OMIM 610842) } \\
\text { Autosomal recessive vitamin } \\
\text { K-dependent coagulation } \\
\text { defect (OMIM 277450) }\end{array}$ & $\begin{array}{l}\text { Only } 50 \% \text { of expected Ggcx(-/-) } \\
\text { mice survive to term but the } \\
\text { latter animals die uniformly at } \\
\text { birth of massive intra-abdominal } \\
\text { hemorrhage. A } 28 \mathrm{~kb} \text { duplication } \\
\text { containing this gene and TAT2A } \\
\text { was reported in a normal control } \\
\text { person. }\end{array}$ \\
\hline VAMP8 & $\begin{array}{l}\text { Vesicle-associated } \\
\text { membrane protein } \\
8\end{array}$ & $\begin{array}{l}\text { Vesicle-associated } \\
\text { membrane protein } 8\end{array}$ & $\begin{array}{l}\text { Fusion of synaptic } \\
\text { vesicles with the } \\
\text { presynaptic } \\
\text { membrane }\end{array}$ & None & $\begin{array}{l}\text { Homozygous knock-out mice } \\
\text { exhibit background-sensitive } \\
\text { postnatal lethality, } \\
\text { hydronephrosis, and reduced } \\
\text { amylase secretion, type I } \\
\text { hypersensitivity reaction, and } \\
\text { platelet activation. }\end{array}$ \\
\hline VAMP5 & $\begin{array}{l}\text { Vesicle-associated } \\
\text { membrane protein } \\
5\end{array}$ & $\begin{array}{l}\text { Vesicle-associated } \\
\text { membrane protein } 5\end{array}$ & $\begin{array}{l}\text { Docking and/or } \\
\text { fusion of vesicles } \\
\text { and cell membranes }\end{array}$ & None & No knock-out mice. \\
\hline RNF181 & $\begin{array}{l}\text { Ring finger protein } \\
181\end{array}$ & $\begin{array}{l}\text { E3 ubiquitin-protein } \\
\text { ligase RNF181 }\end{array}$ & $\begin{array}{l}\text { E3 ubiquitin ligase } \\
\text { activity }\end{array}$ & None & $\begin{array}{l}\text { No knock-out mice. A } 36 \text { kb } \\
\text { deletion encompassing the } \\
\text { whole gene was reported in a } \\
\text { normal control person. }\end{array}$ \\
\hline TMEM150A & $\begin{array}{l}\text { Transmembrane } \\
\text { protein 150A }\end{array}$ & $\begin{array}{l}\text { Transmembrane } \\
\text { protein } 150 \text { A precursor }\end{array}$ & Unknown & None & No knock-out mice. \\
\hline C2orf68 & $\begin{array}{l}\text { Chromosome } 2 \\
\text { open reading frame }\end{array}$ & $\begin{array}{l}\text { UPF0561 protein } \\
\text { C2orf68 }\end{array}$ & Unknown & None & No knock-out mice. \\
\hline
\end{tabular}


Table 2 Genes located at the duplicated region of 2p11.2 (Continued)

\begin{tabular}{|c|c|c|c|c|c|}
\hline \multirow[t]{2}{*}{ USP39 } & $\begin{array}{l}\text { Ubiquitin specific } \\
\text { peptidase } 39\end{array}$ & $\begin{array}{l}\text { U4/U6.U5 tri-snRNP- } \\
\text { associated protein } 2\end{array}$ & $\begin{array}{l}\text { Ubiquitin } \\
\text { thiolesterase activity, } \\
\text { zinc ion binding }\end{array}$ & None & $\begin{array}{l}\text { No knock-out mice. } \\
\text { A } 12 \text { kb deletion encompassing } \\
\text { exons } 4-6 \text { and a } 5.6 \text { kb deletion } \\
\text { encompassing exons } 7-9 \text { was } \\
\text { reported in normal control } \\
\text { persons. }\end{array}$ \\
\hline & & & & & $\begin{array}{l}\text { Not affected by our duplication } \\
\text { based on qRT-PCR result. }\end{array}$ \\
\hline
\end{tabular}

CTNNB1 [catenin (cadherin-associated protein), beta 1, MIM 116806] [19], mutations of which cause severe intellectual disability with absent or very limited speech, microcephaly, and spasticity [20]. Since proteins accomplish most of their functions by interacting with other molecules, we wondered whether TCF7L1 might be involved in intellectual disability by increasing gene dosage from the duplication. Theoretically, TCF7L1 at the distal duplication junction would express one intact and one truncated transcript, respectively (Figure 4). The truncated one with $3^{\prime}$ end is most likely not expressed due to the lack of the promotor and putative start codon. This was confirmed by qRT-PCR with two different primer pairs-\#1 and \#2 designed from the $5^{\prime}$ end and $3{ }^{\prime}$ end of this gene (Figures $3 \mathrm{~A}$ and 4, Table 1), which failed to demonstrate any change in expression in the patient, her healthy mother, and sister (data not shown). This finding makes it highly unlikely that TCF7L1 is a candidate for intellectual disability.

The gene USP39 (ubiquitin specific peptidase 39, MIM 611594) is also a good candidate for intellectual disability since alterations of the ubiquitin/proteasome system (UPS) may engender neuronal dysfunction leading to neurological disease and intellectual disability [21]. This gene truncated at the proximal duplication junction would consequently be predicted to produce one intact and one truncated transcript with the $5^{\prime}$ end (Figure 4). Two primer pairs \#4 and \#5 were designed from the 5 ' end and 3' end of this gene, respectively, for qRT-PCR (Figure 4 and Table 1). The amount of transcript (from two different regions) was not different in the patient, her unaffected mother, and sister (data not shown), suggesting that this gene is not affected by the duplication.

Since the transcription of two truncated genes, TCF7L1 and USP39, is in the same direction, there is a possibility of producing a fusion gene (Figure 4). Practically, it is unlikely that the fusion gene is expressed. If it had been expressed, the amplicon from primer pair \#2 would have shown overexpression due to additional expression from the second half of the fusion gene comprising of partial TCF7L1 with the 3 ' end (Figure 4). This hypothesis that the fusion gene was not expressed is confirmed because RT-PCR failed to demonstrate the presence of the putative fusion gene
USP39/TCF7L1 (data not shown), using a forward primer from USP39 and a reverse primer from TCF7L1, (Figure 4 and Table 1).

After eliminating TCF7L1 and USP39, two partially duplicated but unaffected genes, VAMP8 and RNF181 become plausible candidate genes for intellectual disability seen in our patient among the 13 genes duplicated at 2p11.2. VAMP8 (vesicle-associated membrane protein 8, MIM 603177) encodes a protein involved in the fusion of synaptic vesicles with the presynaptic membrane. It interacts with YWHAE (tyrosine 3-monooxygenase/tryptophan 5-monooxygenase activation protein, epsilon polypeptide, MIM 605066) [22]. Heterozygous knockout mice show neuron migration defects, mild defects in spatial working memory, and possibly enhanced anxiety in an elevated plus-maze test. This phenotype coupled with the genetic association between one SNP in the 5' flanking region of YWHAE and schizophrenia suggested this gene a possible susceptibility gene for this psychiatric disorder [23]. This makes VAMP8 an attractive candidate gene for intellectual disability. RNF181 (ring finger protein 181, MIM 612490) has E3 ubiquitin ligase activity [24] and because ubiquitination plays a crucial role in neurodevelopment as aforementioned [21], this is a good candidate for intellectual disability.

At least, five genes, HUWE1 (MIM 300697), PARK2 (MIM 602544), UBE3A (MIM 601623), UBE3B (MIM 608047), RNF216 (MIM 609948), encoding E3 ubiquitin ligases, have been involved in intellectual disability or another neurological phenotype. Mutations of HUWE1 (HECT, UBA and WWE domain containing 1) are associated with X-linked intellectual disability [25] and PARK2 (Parkinson protein 2) is mutated in Parkinson patients [26]. Genetic alterations of $U B E 3 A$ (ubiquitin protein ligase E3A) cause Angelman syndrome characterized by intellectual disability, seizures, frequent smiling and laughter, and abnormal gait [27]. Biallelic loss-offunction mutations of $\angle B E 3 B$ (ubiquitin protein ligase E3B) cause autosomal recessive blepharophimosis-ptosisintellectual-disability syndrome [28]. Inactivating mutations of RNF216 (ring finger protein 216) cause Gordon Holmes syndrome, which is characterized by cerebellar ataxia, dementia, and hypogonadotropic hypogonadism [29]. 
Additionally, CUL4B (cullin 4B, MIM 300304) associated with syndromic X-linked intellectual disability is a scaffold subunit of E3 ubiquitin-protein ligase complex [30] and $U B E 2 A$ (ubiquitin-conjugating enzyme E2A, MIM 312180) encoding E2 ubiquitin-conjugating enzyme are associated with X-linked intellectual disability [31]. An unaffected individual with a $36 \mathrm{~kb}$ deletion encompassing whole gene RNF181 has been reported as aforementioned [13]. However, we still cannot exclude the possibility that overexpression from a duplication, which was confirmed by qRT-PCR (Figure 3F), rather than haploinsufficiency, might cause intellectual disability.

Among the duplicated genes, CAPG [capping protein (actin filament), gelsolin-like, MIM 153615] encodes a macrophage-capping protein, which controls actin-based motility in non-muscle cells. Homozygous mutant mice lacking this gene manifest increased susceptibility to some bacterial infections [32]. This gene might also have had some influence on the patients' phenotype as a result of the duplication, given that qRT-PCR showed its overexpression in our patient with recurrent fungal infection on the skin of her hands (Figures 1I, J, and 3D). The patient commonly placed her hands into her mouth, biting her fingers with self-injurious behavior. Her skin lesions were sometimes complicated with fungal infections and treated with antifungal cream, clotrimazole.

Lastly, two genes, ELMOD3 and GGCX, involved in recessive disorders were ruled out as candidate genes because of the absence of associated clinical features of these two genes in our patient with a likely autosomal dominant phenotype due to the heterozygous duplication. A homozygous missense mutation of ELMOD3 (ELMO/CED-12 domain containing 3, MIM 615427) was found by whole exome sequencing combined with homozygosity mapping in a Pakistani family with autosomal recessive nonsyndromic deafness-88 (DFNB88, MIM 615429) [33], while homozygous missense and compound heterozygous mutations of GGCX (gammaglutamyl carboxylase, MIM 137167) cause vitamin Kdependent coagulation defect (MIM 277450) [34,35] and pseudoxanthoma elasticum-like Disorder with multiple coagulation factor deficiency (MIM 610842) [36].

\section{Conclusions}

In summary, here we report the first interstitial duplication of 2p11.2 associated with syndromic intellectual disability. Based on the functional characterization and qRT-PCR of the genes, we suggest three positional candidate genes-VAMP8 and RNF181 for intellectual disability and CAPG for recurrent infection. In concert with the qRT-PCR data, we propose increased gene dosage as the underlying mechanism of the two phenotypes.

\section{Methods}

For high resolution karyotype, peripheral blood lymphocytes from the patient, mother, and younger sister were cultured with Phytohematoagglutinin and harvested for cytogenetic analysis using standard techniques. Chromosome analysis was performed on GTL-banded chromosomes at an approximately 550 band level.

Methylation studies of the $15 \mathrm{q} 11-\mathrm{q} 13$ region was performed with enzymes HindIII and CfoI and Southern blot analysis with probe $P W 71 B$.

DNA copy number variants were investigated using a $400 \mathrm{k}$ whole genome oligonucleotide array (GPL9777) employing the protocols for array $\mathrm{CGH}$ provided by the manufacturer (Agilent, Santa Clara, USA). Image analysis, normalization, and annotation were done with Feature Extraction 10.5.1.1 (Agilent, Santa Clara, USA) using the default settings. Data visualization and further analysis was performed with GenomeCAT (http:// www.molgen.mpg.de/ abt_rop/molecular_cytogenetics/ CGHPRO.html). CNVs were determined by circular binary segmentation [37].

To confirm the duplicated region, three primer pairs were designed for real-time quantitative PCR (qPCR)pairs \#1 and \#2 from the $5^{\prime}$ and $3^{\prime}$ ends of the gene TCF7L1, respectively, and \#3 from the gene TMEM150A (Figure 3A, Table 1). Primer pair \#1 was designed from the outside of the duplicated region as a negative control, whereas primer pairs \#2 and \#3 were designed from within the duplicated region (Figure 3A). qPCR was performed using an ABI 7300 Realtime PCR system (Applied Biosystem, Foster City, CA, USA) according to the manufacturer's instructions (Figure $3 C$ ). The copy number was measured relative to GAPDH.

For real-time reverse transcriptase quantitative PCR (qRT-PCR), RNA was extracted from lymphoblastoid cell lines by Trizol Reagent (Invitrogen, Calsbad, CA, USA). Total RNA was reverse-transcribed into cDNA by RevertAid First-strand cDNA synthesis (Thermo Fisher Scientific, Glen Burnie, MA, USA). qRT-PCR for TCF7L1, CAPG, VAMP8, RNF181, and USP39 was performed with SYBR (RT2 SYBR Green, Qiagen, Gaithersburg, MD, USA) on an ABI 7300 Realtime PCR system (Applied Biosystem, Foster City, CA, USA) according to the manufacturer's instructions. For three genes, TCF7L1, CAPG, and USP39, two primer pairs were designed per gene, whereas one primer pair was designed for two genes, VAMP8 and RNF181 (Table 1).

To amplify the putative fusion gene USP39/TCF7L1, reverse transcriptase PCR (RT-PCR) was performed with a forward primer from USP39 and a reverse primer from TCF7L1, respectively. The forward primer was designed from exon 6 of USP39 because the breakpoint was located between intron 7 (minimum breakpoint) and intron 10 (maximum breakpoint), and an exon 7 fragment 
is too small to analyze. The reverse primer was designed complementary to exon 5 of TCF $L 1$, since the breakpoint lies in intron 3 and exon 4 is too short (Figure 4, Table 1).

To better define the clinical phenotype associated with copy number variation of $2 \mathrm{p} 11.2$, we compared this case with previously reported interstitial deletions encompassing 2p11.2 and assigned individual phenotypes to individual genes in the duplicated region.

Ethical approval was granted for this study by an interdisciplinary institutional reviewer board of Georgia Regents University.

\section{Consent}

Written informed consent was obtained from the patient's mother for the publication of this report and any accompanying images.

\section{Abbreviations}

aCGH: Array comparative genomic hybridization; EEG: Electroencephalography; FISH: Fluorescent in situ hybridization; qPCR: Real-time quantitative PCR; qRT-PCR: Real-time reverse transcriptase quantitative PCR.

\section{Competing interests}

The authors declare that they no competing interest.

\section{Authors' contributions}

KRJ drafted the manuscript with HGK. HGK supervised the design of the study and edited the manuscript. RU performed microarray. SK and LCL interpreted the results and reviewed the manuscript with many constructive suggestions. All authors have read and approved the final manuscript.

\section{Acknowledgements}

This paper is dedicated to Paulita, who lost her battle with multisystem syndrome on September 6th of 2012. She was the beloved daughter and sister of the family. We thank Hyun Min Cho for performing q-PCR and GRT-PCR.

\section{Author details}

${ }^{1}$ Department of Laboratory Medicine, Inje University Haeundae Paik Hospital, Busan, South Korea. ${ }^{2}$ Department of Human Molecular Genetics, Max Planck Institute for Molecular Genetics, Berlin, Germany. ${ }^{3}$ Department of Biotechnology \& Genetic engineering, Kohat University of Science \& Technology (KUST), Kohat, Khyber Pakhtunkhwa, Pakistan. ${ }^{4}$ Section of Reproductive Endocrinology, Infertility \& Genetics, Department of Obstetrics and Gynecology, Institute of Molecular Medicine and Genetics, Medical College of Georgia, Georgia Regents University, 1120 15th Street, Augusta, Georgia. ${ }^{5}$ Neuroscience Program, Medical College of Georgia, Georgia Regents University, Augusta, Georgia.

Received: 8 May 2014 Accepted: 20 June 2014 Published: 19 August 2014

\section{References}

1. Larson LM, Wasdahl WA, Saumur JH, Coleman ML, Hall JG, Dolan CR, Schutta CJ: Familial reciprocal translocation, $\mathrm{t}(2 ; 10)(\mathrm{p} 24 ; \mathrm{q} 26)$, resulting in duplication 2p and delection 10q. Clin Genet 1982, 21:187-195.

2. Lurie IW, llyina HG, Gurevich DB, Rumyantseva NV, Naumchik IV, Castellan C, Hoeller A, Schinzel A: Trisomy 2p: analysis of unusual phenotypic findings. Am J Med Genet 1995, 55:229-236.

3. Atik T, Durmaz B, Yorganci OU, Cogulu O, Kioutsouk M, Ozkinay F: Partial trisomy 2p24- pter and monosomy 18q22.1- qter resulting from parental translocation. Genet Couns 2013, 24:179-184.

4. Siffroi JP, Molina-Gomez D, Viguie F, Nessmann C, Dadoune JP: Prenatal diagnosis of partial $2 p$ trisomy by 'de novo' duplication $2 p(13.1-21)$. Confirmation by FISH. Prenat Diagn 1994, 14:1097-1099.
5. Aviram-Goldring A, Fritz B, Bartsch C, Steuber E, Daniely M, Lev D, Chaki R, Barkai G, Frydman M, Rehder H: Molecular cytogenetic studies in three patients with partial trisomy $2 \mathrm{p}$, including $\mathrm{CGH}$ from paraffin-embedded tissue. Am J Med Genet 2000, 91:74-82.

6. Thangavelu M, Frolich G, Rogers D: Partial duplication $2 p$ as the sole abnormality in two cases with anencephaly. Am J Med Genet A 2004 124A:170-172.

7. Blassnig-Ezeh A, Bandelier C, Frühmesser A, Revencu N, Krabichler B, Beauloye V, Ravoet M, Fauth C, Zschocke J, Simma B, Kotzot D: Severe growth retardation, delayed bone age, and facial dysmorphism in two patients with microduplications in 2p16 - p22. Am J Med Genet A 2013, 161A:3176-3181.

8. Dodé C, Levilliers J, Dupont JM, De Paepe A, Le Dû N, Soussi-Yanicostas N, Coimbra RS, Delmaghani S, Compain-Nouaille S, Baverel F, Pêcheux C, Le Tessier D, Cruaud C, Delpech M, Speleman F, Vermeulen S, Amalfitano A, Bachelot Y, Bouchard P, Cabrol S, Carel JC, Delemarre van de Waal H, Goulet-Salmon B, Kottler ML, Richard O, Sanchez-Franco F, Saura R, Young J, Petit C, Hardelin JP: Loss-of-function mutations in FGFR1 cause autosomal dominant Kallmann syndrome. Nat Genet 2003, 33:463-465.

9. Vissers LE, van Ravenswaaij CM, Admiraal R, Hurst JA, de Vries BB, Janssen IM, van der Vliet WA, Huys EH, de Jong PJ, Hamel BC, Schoenmakers EF, Brunner HG, Veltman JA, van Kessel AG: Mutations in a new member of the chromodomain gene family cause CHARGE syndrome. Nat Genet 2004, 36:955-957.

10. Chieri $P$, lölster N: Monosomy 10qter due to a balanced maternal translocation: t(10;8)(q23;p23). Clin Genet 1983, 24:147-150.

11. Wang K, Li M, Hadley D, Liu R, Glessner J, Grant SF, Hakonarson H, Bucan M: PennCNV: an integrated hidden Markov model designed for highresolution copy number variation detection in whole-genome SNP genotyping data. Genome Res 2007, 17:1665-1674.

12. Kidd JM, Cooper GM, Donahue WF, Hayden HS, Sampas N, Graves T, Hansen N, Teague B, Alkan C, Antonacci F, Haugen E, Zerr T, Yamada NA, Tsang P, Newman TL, Tüzün E, Cheng Z, Ebling HM, Tusneem N, David R, Gillett W, Phelps KA, Weaver M, Saranga D, Brand A, Tao W, Gustafson E, McKernan K, Chen L, Malig M, et al: Mapping and sequencing of structural variation from eight human genomes. Nature 2008, 453:56-64.

13. Pang AW, MacDonald JR, Pinto D, Wei J, Rafiq MA, Conrad DF, Park H, Hurles ME, Lee C, Venter JC, Kirkness EF, Levy S, Feuk L, Scherer SW: Towards a comprehensive structural variation map of an individual human genome. Genome Biol 2010, 11:R52.

14. Wheeler DA, Srinivasan M, Egholm M, Shen Y, Chen L, McGuire A, He W, Chen YJ, Makhijani V, Roth GT, Gomes X, Tartaro K, Niazi F, Turcotte CL, Irzyk GP, Lupski JR, Chinault C, Song XZ, Liu Y, Yuan Y, Nazareth L, Qin X, Muzny DM, Margulies M, Weinstock GM, Gibbs RA, Rothberg JM: The complete genome of an individual by massively parallel DNA sequencing. Nature 2008, 452:872-876

15. Mills RE, Luttig CT, Larkins CE, Beauchamp A, Tsui C, Pittard WS, Devine SE: An initial map of insertion and deletion (INDEL) variation in the human genome. Genome Res 2006, 16:1182-1190.

16. Tzschach A, Graul-Neumann LM, Konrat K, Richter R, Ebert G, Ullmann R, Neitzel $\mathrm{H}$ : Interstitial deletion 2p11.2-p12: report of a patient with mental retardation and review of the literature. Am J Med Genet A 2009, 149A:242-245.

17. Barber JC, Thomas NS, Collinson MN, Dennis NR, Liehr T, Weise A, Belitz B, Pfeiffer L, Kirchhoff M, Krag-Olsen B, Lundsteen C: Segmental haplosufficiency: transmitted deletions of $2 p 12$ include a pancreatic regeneration gene cluster and have no apparent phenotypic consequences. Eur J Hum Genet 2005, 13:283-291.

18. MacDonald BT, Tamai $K$, He X: Wnt/beta-catenin signaling: components, mechanisms, and diseases. Dev Cell 2009, 17:9-26.

19. Graham TA, Clements WK, Kimelman D, Xu W: Crystal structure of a beta-catenin/Tcf complex. Cell 2000, 103:885-896.

20. de Ligt J, Willemsen MH, van Bon BW, Kleefstra T, Yntema HG, Kroes T, Vulto-van Silfhout AT, Koolen DA, de Vries P, Gilissen C, del Rosario M, Hoischen A, Scheffer $H$, de Vries BB, Brunner HG, Veltman JA, Vissers LE: Diagnostic exome sequencing in persons with severe intellectual disability. N Engl J Med 2012, 367:1921-1929.

21. Tai HC, Schuman EM: Ubiquitin, the proteasome and protein degradation in neuronal function and dysfunction. Nat Rev Neurosci 2008, 9:826-838.

22. Gloeckner CJ, Boldt K, Schumacher A, Roepman R, Ueffing M: A novel tandem affinity purification strategy for the efficient isolation and 
characterisation of native protein complexes. Proteomics 2007, 7:4228-4234.

23. Ikeda M, Hikita T, Taya S, Uraguchi-Asaki J, Toyo-oka K, Wynshaw-Boris A, Ujike H, Inada T, Takao K, Miyakawa T, Ozaki N, Kaibuchi K, Iwata N: Identification of YWHAE, a gene encoding 14-3-3epsilon, as a possible susceptibility gene for schizophrenia. Hum Mol Genet 2008, 17:3212-3222.

24. Brophy TM, Raab M, Daxecker H, Culligan KG, Lehmann I, Chubb AJ, Treumann A, Moran N: RN181, a novel ubiquitin E3 ligase that interacts with the KVGFFKR motif of platelet integrin alpha(Ilb)beta3. Biochem Biophys Res Commun 2008, 369:1088-1093.

25. Froyen G, Corbett M, Vandewalle J, Jarvela I, Lawrence O, Meldrum C, Bauters M, Govaerts K, Vandeleur L, Van Esch H, Chelly J, Sanlaville D, van Bokhoven $\mathrm{H}$, Ropers HH, Laumonnier F, Ranieri E, Schwartz CE, Abidi F, Tarpey PS, Futreal PA, Whibley A, Raymond FL, Stratton MR, Fryns JP, Scott R, Peippo M, Sipponen M, Partington M, Mowat D, Field M, et al: Submicroscopic duplications of the hydroxysteroid dehydrogenase HSD17B10 and the E3 ubiquitin ligase HUWE1 are associated with mental retardation. Am J Hum Genet 2008, 82:432-443.

26. Kitada T, Asakawa S, Hattori N, Matsumine H, Yamamura Y, Minoshima S, Yokochi M, Mizuno $Y$, Shimizu N: Mutations in the parkin gene cause autosomal recessive juvenile parkinsonism. Nature 1998, 392:605-608.

27. Kishino T, Lalande M, Wagstaff J: UBE3A/E6-AP mutations cause Angelman syndrome. Nat Genet 1997, 15:70-73.

28. Basel-Vanagaite L, Dallapiccola B, Ramirez-Solis R, Segref A, Thiele H, Edwards A, Arends MJ, Miró X, White JK, Désir J, Abramowicz M, Dentici ML, Lepri F, Hofmann K, Har-Zahav A, Ryder E, Karp NA, Estabel J, Gerdin AK, Podrini C, Ingham NJ, Altmüller J, Nürnberg G, Frommolt P, Abdelhak S, Pasmanik-Chor M, Konen O, Kelley Rl, Shohat M, Nürnberg P, et al: Deficiency for the ubiquitin ligase UBE3B in a blepharophimosisptosis-intellectual-disability syndrome. Am J Hum Genet 2012, 91:998-1010.

29. Margolin DH, Kousi M, Chan YM, Lim ET, Schmahmann JD, Hadjivassiliou M, Hall JE, Adam I, Dwyer A, Plummer L, Aldrin SV, O'Rourke J, Kirby A, Lage K, Milunsky A, Milunsky JM, Chan J, Hedley-Whyte ET, Daly MJ, Katsanis N, Seminara SB: Ataxia, dementia, and hypogonadotropism caused by disordered ubiquitination. N Engl J Med 2013, 368:1992-2003.

30. Tarpey PS, Raymond FL, O'Meara S, Edkins S, Teague J, Butler A, Dicks E, Stevens C, Tofts C, Avis T, Barthorpe S, Buck G, Cole J, Gray K, Halliday K, Harrison R, Hills K, Jenkinson A, Jones D, Menzies A, Mironenko T, Perry J, Raine K, Richardson D, Shepherd R, Small A, Varian J, West S, Widaa S, Mallya $U$, et al: Mutations in CUL4B, which encodes a ubiquitin E3 ligase subunit, cause an X-linked mental retardation syndrome associated with aggressive outbursts, seizures, relative macrocephaly, central obesity, hypogonadism, pes cavus, and tremor. Am J Hum Genet 2007, 80:345-352.

31. Nascimento RM, Otto PA, de Brouwer AP, Vianna-Morgante AM: UBE2A, which encodes a ubiquitin-conjugating enzyme, is mutated in a novel X-linked mental retardation syndrome. Am J Hum Genet 2006, 79:549-555.

32. Parikh SS, Litherland SA, Clare-Salzler MJ, Li W, Gulig PA, Southwick FS: CapG(-/-) mice have specific host defense defects that render them more susceptible than $\mathrm{CapG}(+/+)$ mice to Listeria monocytogenes infection but not to Salmonella enterica serovar Typhimurium infection. Infect Immun 2003, 71:6582-6590.

33. Jaworek TJ, Richard EM, Ivanova AA, Giese AP, Choo DI, Khan SN, Riazuddin S, Kahn RA, Riazuddin S: An alteration in ELMOD3, an Arl2 GTPaseactivating protein, is associated with hearing impairment in humans. PLoS Genet 2013, 9:e1003774.

34. Brenner B, Sánchez-Vega B, Wu SM, Lanir N, Stafford DW, Solera J: A missense mutation in gamma-glutamyl carboxylase gene causes combined deficiency of all vitamin K-dependent blood coagulation factors. Blood 1998, 92:4554-4559.

35. Rost S, Fregin A, Koch D, Compes M, Müller CR, Oldenburg J: Compound heterozygous mutations in the gamma-glutamyl carboxylase gene cause combined deficiency of all vitamin K-dependent blood coagulation factors. Br J Haematol 2004, 126:546-549.
36. Vanakker OM, Martin L, Gheduzzi D, Leroy BP, Loeys BL, Guerci VI, Matthys D, Terry SF, Coucke PJ, Pasquali-Ronchetti I, De Paepe A: Pseudoxanthoma elasticum-like phenotype with cutis laxa and multiple coagulation factor deficiency represents a separate genetic entity. J Invest Dermatol 2007, 127:581-587.

37. Olshen $A B$, Venkatraman ES, Lucito $R$, Wigler M: Circular binary segmentation for the analysis of array-based DNA copy number data. Biostatistics 2004, 5:557-572.

doi:10.1186/1755-8166-7-52

Cite this article as: Jun et al:: Interstitial microduplication at 2p11.2 in a patient with syndromic intellectual disability: 30-year follow-up.

Molecular Cytogenetics 2014 7:52.

\section{Submit your next manuscript to BioMed Central and take full advantage of:}

- Convenient online submission

- Thorough peer review

- No space constraints or color figure charges

- Immediate publication on acceptance

- Inclusion in PubMed, CAS, Scopus and Google Scholar

- Research which is freely available for redistribution

Submit your manuscript at www.biomedcentral.com/submit
C) Biomed Central 